\title{
Public-private partnerships in the provision of homeopathic services in the city of Delhi, India
}

\author{
A Venkat Raman ${ }^{1}$, Raj Kumar Manchanda ${ }^{2}$ \\ (1)Faculty of Management Studies, University of Delhi, Delhi \\ (2)Deputy Director (Homoeopathy), Government of Delhi, India
}

\begin{abstract}
Homeopathy is one among the popular medical systems in India. Over the years, the government has been attempting to mainstream homeopathy in the public health system, nevertheless, most service providers are in the private sector. Therefore, increase of quality and availability to all population classes by means of public-private partnerships is seen as a viable policy option. In Delhi, 90\% of homeopathic services providers belong to the private sector, including charity trusts. Most of them provide services to the low-income population in urban slams. In 2003, Delhi government launched a program involving the private sector to provide homeopathic services in underserved city areas. This project funded private agencies to run homeopathic clinics. This paper provides an overview on this program, addressing in particular the lessons taught by six case studies represented by non-governmental organizations (NGOs). It also discusses expectations of private providers and concludes with specific recommendations for wider participation of the private sector.
\end{abstract}

Keywords: Public-private partnership, Homeopathic services, Delhi, Non-governmental organization, cost-effectiveness, critical success factors

\section{Introduction}

Background: Traditional systems of medicine - collectively known as AYUSH (Ayurveda, Yoga \& Naturopathy, Unani, Siddha and Homeopathy) - are widely accepted by Indian society and enjoy government support. As a fact, the government expects AYUSH to play a vital role in health care [1-8]. Since the private sector is a predominant provider of health-care services, public-private partnership (PPP) is advocated as a sound policy option [9].

Homeopathy is not indigenous to India, but it rates as one of the most popular medical systems in the country[1-10]. It currently comprises 234 hospitals and 5,910 dispensaries with 10,933 beds, 217,860 registered practitioners, and 186 colleges (35 govt.). The homeopathic market was estimated at about Rs. 26 billion (USD 550 million) for 2010 with 25-30\% growth (ASSOCHAM 2007)[11]. (Rs.100 equals to approximately USD 2.2 ) 
Homeopathic services in Delhi: Out of estimated 5,000 homeopathic practitioners in the city of Delhi, 90\% are considered to act in the private sector. There are 149 government dispensaries and about 600 charity dispensaries in the city. Anecdotal evidence suggests that most dispensaries are run by single practitioners who charge nominal fees. It is alleged that private sector tend to employ self-taught, unqualified, unregistered practitioners. It is argued that involvement of private providers will improve the quality of homeopathy services by ensuring the employment of only qualified and skilled Homeopathic doctors, strengthen the public health system, wean away people from quacks, improve access to health care at relatively low cost, help mainstream the homeopathy system, and avoid malpractice. With these objectives, a program was launched in 2003 to establish ten PPP dispensaries, the initial five were established in January, and the remainder in 2006. This study aimed at evaluating the performance of these dispensaries, seeking to strengthen future partnerships.

Study design: Case studies of six non-governmental organizations (NGOs) with mixed performance leveltwo each from successful, partially successful and unsuccessful experiences. Primary data were gathered by means of interviews with doctors, paramedics, patients and management. Data were also collected from official records and reports submitted by NGOs.

\section{Case Analysis}

Highlights of the case studies are given below:

Case 1 (G. P. J.): Registered in 1980 and located in an upper class urban area, its services, however, are mostly used by domestic servants, daily wagers, and migrant labour from a nearby slum cluster. The clinic opened for two hours daily and treated average 15 patients per day. Meagre fees (Rs 2,500-3,000/ less than 70 USD per month) made it difficult to hire and/or keep doctors. As a result, the dispensary was dysfunctional and losses were funded by a trust. After PPP was established in February 2003, services were increased to six hours per day in two shifts. Larger room was made available including a doctor office, a dispensing office and a waiting area. Two homeopathic doctors were hired through newspaper advertisement. One pharmacist and one assistant were also appointed. During the following five years, the trust received financial support from the government. A total of 53, 072 patients attended the clinic during these five years at an average of 10,600 patients per year (average 35 patients per day in 300 days-clinic per year). PPP definitely resulted in increased patients volume, better accessibility through increased service hours, and ensured availability of sufficient human resources. Cost of care per patient was Rs. 21.30 (about USD 50 cents), whereas government subsidy was only about $30 \%$. Specific concerns are related to delayed payment, delayed government audit report, and lack of capacity of NGO to optimally apply funds. Management expressed dissatisfaction on several fronts. Staff was concerned about low wages. Patients rated services better compared to the nearest public dispensary and many private clinics.

Case 2: (S. N. M.) Registered in 1948 as a religious trust, it runs educational institutions and medical facilities. A homeopathic dispensary was established 1994 adjacent to an allopathic hospital in a semi-urban area. The dispensary caters to people who attend religious ceremonies or to rural migrants. Prior to PPP, it open only two hours and attracted about 20 patients per day. In April 2006, PPP was established and response was overwhelming. The clinic used to treat 5, 091 patients annually, but witnessed a five-fold increase $(25,998)$ in the first year, and continued to increase in the second and third years of operation. Although accounts have been already audited, funds have not yet been released. Data also show low average cost of treatment per patient (Rs. 9.15 or < USD20 cents); government subsidy is close to 60\%. Causes of concern are delayed funds release and inability to audit the dispensary performance on a steady basis. One of the suggestions was for the government to release funds in one only instalment. 
Case 3 (M. D. D.): Registered in 1997, this NGO is engaged in community-based literacy activities in a slum. Under PPP it set up a dispensary in 2003. A daughter of a trustee who is a homeopathic doctor was appointed to the dispensary. Patients predominantly belonged to the slum community. The dispensary functioned for only three hours in the morning. Approximately 15 patients attended the dispensary each day, however, the number has been declining during the past two years. One of the key lessons from this dispensary is that an agency might run a homeopathy dispensary with no additional cost if the government increases budget allocation marginally. Average cost per patient was Rs. 24. 61 (about USD 60 cents), government subsidy is about 55\%. Though the dispensary performance in terms of patient load is not appreciable, the financial aspects provide valuable lessons to redesign the program. Besides delayed payment, non-availability of an additional doctor due to low fees and inadequate training of doctors by the government are indicated as causes of concern. Management was especially critical about unspent funds deduction and low wages. Patients expressed dissatisfaction with non-availability of doctor in the evening.

Case 4 (H. N.I.W): Registered in 1990, this NGO undertakes social and cultural activities among industrial labourers. This NGO had no previous experience in the health sector, but it was willing to work with the government and open a new dispensary. The NGO started its homeopathic dispensary in February 2003. Average patient load was 20 to 25 per day in the first three years and declined to less than 10 in the last year. The dispensary functioned only three hours every day in the morning. The NGO does not seem to be able to sustain the dispensary, since it had to meet an additional expense from its own funds. The average cost per patient is calculated to be Rs. 19. 56 (40 cents), with government subsidy at 50\%. Performance of the dispensary in terms of patient load decayed due to management inability to maintain the services. The NGO also showed unspent funds, leading to delay in further fund flow.

Case 5 (V. C. A.): Run by a religious organization, this NGO established a homoeopathic dispensary in the premises of a temple in February 2003. The doctor himself a trustee, was reportedly irregular, therefore patient load was always suboptimal. Since the dispensary was located in a far-flung area, it was not visited by government officials regularly. It could not collect enough fees from patients and the dispensary was under deficit. It was found out that doctor was compensating deficit from his own pocket. Cost per patient was Rs 36.5 (USD 80 cents), and government subsidy was $80 \%$. The partnership could barely work for two years.

Case 6: (C. S. M.): Established in 1992, CSM is a registered trust, which provides vocational training including computer teaching to children from low income groups. The trust had prior experience in organizing AIDS awareness camps and drug de-addiction rallies. In January 2003, the trust established a homeopathic dispensary under PPP. However, during a review meeting in March 2003, the society claimed it had started

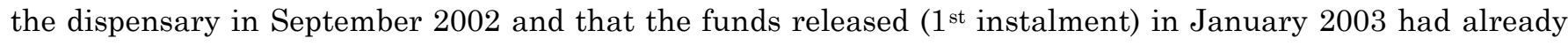
been spent. Further it informed that a theft had taken place in the dispensary and all furniture, drugs, etc. had been stolen. It also claimed that a dispute developed with the owner of the house, which was on lease. A copy of the complaint filed with the police and other agencies was produced as evidence. The NGO insisted that it was already in deficit and that the remainder of the $1^{\text {st }}$ instalment ought to be released immediately to run the dispensary at a newly rented place. A departmental enquiry revealed that no homeopathy dispensary ever functioned at the original premises approved. The new address given was the NGO president private residence in a locality that is not underserved. Even at the new site, during inspection, outdated -expireddrugs were kept; drug inventory book, patient register and furniture were not available. The NGO claimed that miscreants had destroyed all the records during the theft. An audit report found that the NGO did not maintain any cashbook; receipts were on loose sheets without signatures; vouchers had no serial numbers; there was no stock entry for furniture, drugs, medicines and consumables; and there was no record of fees. Apparently the NGO was trying to mislead the government. The government then directed the police to investigate the case. No breakthrough was made by the investigating authority after 5 years. 


\section{Key-lessons:}

The key-findings and lessons from the case studies are analysed with reference to the performance, outcomes and lessons from the partnership scheme.

Selection of private agencies: Prior consultation, thorough background verification, proven track record, and selection by a panel of eminent citizens could be most appropriate methods in selecting partners. Prior experience in health service delivery, particularly running a dispensary seem to be critical for success. Several NGOs already providing homeopathic services did not participate in the program. The reasons for their lack of enthusiasm need to be identified.

Provision for rent: The program did not have provisions for the renovation or maintenance of buildings, which may have affected the quality of service.

Patient load: Year-wise patient load in the selected dispensaries increased consistently in the successful partnerships. Patient load is clearly dependent on factors like availability of doctors, quality of care, and support from the management. In unsuccessful facilities doctors were irregular or unavailable. It could be inferred that for a moderately successful dispensary, minimum patient load should be around 650-700 patients per month. Availability of more than one competent doctor is also essential to increase patient volume and for subsequent success of the dispensary. Staff performance increases when appointments are not made on the basis of nepotism or favouritism.

Financial sustainability: Due to problems in the identification of poor patients only $5-10 \%$ were treated free rather than the stipulated $25 \%$. User fees collected by each agency showed that this source was not sustained beyond two or three years in partially successful and unsuccessful cases. User fees were not sufficient. Even the most successful NGO stated there was a need of regular donations or government funds to sustain service. It appears that the on-going policy reducing and totally withdrawing funds after five years is not viable, but regular grants beyond this period are essential to maintain services. For this purpose, NGOs should be able to deliver services even when funds are not released in time. It may be important for the program to add a clause compelling to deposit a sum equivalent to six months of operational expenses. The contract must also add a condition according to which NGOs shall be compensated whenever payments are delayed more than 6 months.

Cost-effectiveness: Data regarding cost per patient reveal that the government is able to reach beneficiaries in a more cost-effective manner. Our analysis is based only on the data supplied by four reliable NGOs. Data indicate wide variation in cost, suggesting further control and optimisation through increased patient volume. Average cost per patient in the government dispensary can be as high as Rs. 41.60 (95 cents). In addition, there are administrative expenses, capital costs and recurring expenses that are not included in the analysis. Therefore, it is safer to conclude that cost of treatment in a PPP dispensary is more cost-effective compared to government-run dispensaries. The net cost per patient for the government goes further down in NGO dispensaries funded by the government. Cost per patient might come down if the demand for homeopathic services increases. However, net cost per patient in government run dispensaries is likely to increase further due to the implementation of pay revision.

Delayed release of payment: Release of payments was generally delayed in all the cases due to delays in auditing by the government agencies leading to late clearance of payments. Small NGOs are highly dependent on funding from such programs or donations. Any delay in cash flow even for few months may lead to interruption of service and the patients seeking assistance from alternative sources. Possibility of a timebound, single-window clearance system should be explored. 
Technical and managerial Capacity: Audit reports reveal that most NGOs did not have any knowledge about code formalities, maintenance of accounts and cash flow, inventory and stock register, etc. As a result, some of them had unspent funds that were adjusted in subsequent payments. This resulted in financial hardship and ultimate closure of one dispensary. Even the successful NGOs could not get the full funding due to unspent balance. NGOs require proper training about the utilization of grants. The government needs to provide supportive supervision during the initial phase of the contract.

Risks: Working with the private sector, especially NGOs has an element of financial risk for both government and private agency. Since funds are released by the government, there are distinct possibilities of misappropriation of funds. If the dispensary does not attract sufficient volume of patients, it might be difficult for NGOs to match funds, which may lead to dispensary unsustainability. Another risk is the appointment of (incompetent) staff from among relatives and office bearers of the society, whose performance is not guaranteed and effective supervision by the trust is not possible. There is a need to build in safeguards, like Management Information Systems (MIS) based performance monitoring and accounting for more transparency in the system and reduce such risks.

Monitoring and Reporting: Functioning of the NGOs is inadequately monitored by the government agencies. As a result any downfall in the performance is not addressed immediately. Submission of monthly reports is routine and these reports are not scrutinised for their authenticity. Inspections are carried out only once in a year, whereas it should have been quarterly.

\section{Re-designing the program: Key-considerations}

Based on the experience and lessons from the existing program, the following suggestions are made for redesigning it:

Selection of private partners: Identify underserved areas in Delhi; then identify private providers / NGOs already operational in that area through detailed field survey. A letter detailing the program might be sent to private provider / NGO along with an invitation to participate in the program.

Type of organizations working in the field: They need to be registered for their health service component. This means capacity building and supportive supervision. Over a period, those meeting minimum standards in homeopathic services can be accredited.

Building, rent and maintenance charges: To have a wider choice of partners, provision for rent payment should be considered. For those operating within own premises some fixed sum might be paid for electricity and water, whereas those operating in rented premises a fixed (slightly higher) sum might be allocated as rental and maintenance. Certain proportion or fixed sum might be allocated as annual maintenance grant.

Amount of annual funding and management of funds: Decreasing proportion of funding along five years does not lead to any meaningful engagement with the private providers. These norms need to be revised. The entire focus should be to provide quality services to beneficiaries rather than cost saving. The private partner should be given flexibility to re-allocate unspent balance of funds depending on the dispensary needs.

Release of funds: Release of payments is always delayed due to belated audit and bureaucratic approach of the government officials. A mechanism should be worked out for timely release of funds.

Capacity building: The government should provide orientation training on some administrative formalities and systems such as accounting, stock register, inventory, reporting, etc. Doctors and paramedics should be encouraged to participate in Continued Medical Education (CME) program. 
Reporting \& monitoring: While redesigning the program, a system of e-monitoring should be developed. Relevant data should be uploaded on a daily basis through web-enabled software. Feedback from stakeholders should be collected periodically by placing forms in the dispensary and a suggestion box.

Mainstreaming the homeopathic system: Involve homeopathic dispensaries in health promotion programs such as immunization, Information Education and Communication (IEC), Behaviour Change Communication (BCC) in Mother and Child Health (MCH), birth control, nutrition, disease control, Revised National Tuberculosis Control Program (RNTCP), and others.

Revised program: The essential features of the program are the following:

\section{a) Non-recurring grant}

Non-recurring expenditure grant shall be admissible for renovation of existing dispensary, purchase of furniture, computers and reference books according to requirements. Maximum limit shall be Rs 200,000 ( $\sim$ USD 4,400 ) in the first year. NGO shall contribute $25 \%$ of total expenditure.

\section{b) Recurring grant}

Keeping in mind the findings in the case studies, the estimated recurring annual expenditure on recurring items is described in Table 1.

Table 1: Estimated recurrent annual expenditure

\begin{tabular}{|c|l|r|r|}
\hline S. No. & Activity & $\begin{array}{l}\text { Estimated Monthly } \\
\text { expenditure (Rs) }\end{array}$ & $\begin{array}{l}\text { Estimated Annual } \\
\text { expenditure (Rs) }\end{array}$ \\
\hline 1 & Doctor fees & 30,000 & 360,000 \\
\hline 2 & Pharmacist fees & 7,000 & 84,000 \\
\hline 3 & Assistant fees & 3,000 & 36,000 \\
\hline 4 & Purchase of medicines & 5,000 & 60,000 \\
\hline 5 & Stationery \& printing & 500 & 6,000 \\
\hline 6 & Electricity/water & 1,500 & 18,000 \\
\hline 7 & Accounting charges & 1,000 & 3,000 \\
\hline 8 & Repair/maintenance & 1,000 & 12,000 \\
\hline 9 & Telephone/Internet & & 12,000 \\
\hline 10 & Contingency at $5 \%$ of $4-9$ & & 9,000 \\
\hline & Total & & Rs 600,000 \\
& & $(\sim$ USD 13,200$)$ \\
\hline
\end{tabular}

\section{c) Resource generation by NGOs:}

NGOs shall be allowed to charge Rs. 20/- from every new patient and Rs. 5 per day from old patients as user fees. Below Poverty Line (BPL) cases to be treated free. If the number of free cases exceeds $25 \%$ of total patients, NGO may ask reimbursement of such charges @ Rs 15/- per BPL patient above the 25\% limit. The 
doctor can be authorized to make decisions about determination of BPL status, user fees and eligibility for free treatment.

\section{d) Amount of year-wise grant:}

In order to reduce dependence of NGO on government grants and to help achieving financial independence, it is envisaged to reduce the government grant every year in a stepwise manner. The recurrent expenditure shall be borne by the government and its NGO partner as described in Table 2.

Table 2: Contribution of partners over five years (In Indian Rupees)

\begin{tabular}{|l|c|c|}
\hline \multicolumn{1}{|c|}{ Year } & $\begin{array}{c}\text { Grant in aid to be borne by } \\
\text { the government (\% of total) }\end{array}$ & $\begin{array}{c}\text { Amount to be borne by } \\
\text { NGO (\% of total) }\end{array}$ \\
\hline First year & $540,000(90 \%)$ & $60,000(10 \%)$ \\
\hline Second Year & $480,000(80 \%)$ & $120,000(20 \%)$ \\
\hline Third Year & $360,000(60 \%)$ & $240,000(40 \%)$ \\
\hline Fourth Year & $240,000(40 \%)$ & $360,000(60 \%)$ \\
\hline Fifth Year & $200,000(30 \%)$ & $400,000(70 \%)$ \\
\hline Total & $\mathbf{1 , 8 2 0 , 0 0 0}$ & $\mathbf{1 , 1 8 0 , 0 0 0}$ \\
\hline
\end{tabular}

NGO shall be given a grant of Rs 150,000/- per (25\%) year after five years to sustain the dispensary. NGO shall provide annual pay rise to the staff out surplus collection. It is assumed that if an NGO sees to 50 paid patients every day, by the $4^{\text {th }}$ year, total estimated collection should be Rs 25,000/- per month and Rs $300,000 /-$ per annum. This amount shall be sufficient to meet the matching contribution.

\section{e) Incentive for corpus fund:}

In the $4^{\text {th }}$ year, performance of NGO shall be evaluated using patient load and financial status as performance indicators. If the NGO performs well and is able to generate surplus funds (from user fee or other means) beyond the annual expenditure, it shall be allowed to set up corpus fund with a suitable matching grant from the government. This, it is hoped, shall make the NGOs self-sufficient in the long run.

\section{Conclusion}

Involvement of the private sector in the delivery of health services for underserved sections of the population is increasingly becoming a policy tool for governments across the world. However managing such partnerships presupposes better administrative capacity of the government. Collaboration with the private sector portends enormous potential in achieving to public health objectives.

\section{References}

[1] AYUSH in India Report, Department of AYUSH, Ministry of Health and family welfare GOI (2007)

[2] Annual Report, Ministry of Health \& Family Welfare, Government of India, Page numbers - 75 (Part-I), 223 (Part-II), 267 \& 268 (Part-III) (2004-2005). 
[3] Misra R, Chatterjee R, Rao S. Indian Health Report. New Delhi: Oxford University Press; 2003.

[4] Financing and Delivery of Health Care Services in India, National Commission on Macroeconomics and Health, NCMH Background Papers, Ministry of Health \& Family Welfare, Government of India, Section - II, Delivery of Health Services in the Private Sector, p89 (2005).

[5] National Commission on Macroeconomics and Health, Ministry of Health and Family Welfare, Govt. of India (August 2005).

[6] National Health Policy-2002, Department of Health, Ministry of Health \& Family Welfare, Government of India (2002)

[7] National Policy \& Programmes On Ayurveda, Yoga \& Naturopathy, Unani, Siddha and Homeopathy (AYUSH) (2002)

[8] National Rural Health Mission- Reference Material, Ministry of Health \& Family Welfare, Government of India (2005-2012).

[9] Venkat Raman, A, Björkman JW. Public-Private Partnership in Health care in India, Routledge (2009). Available from: http://www.routledge.com/books/details/9780415467285/

[10] WHO Policy on Traditional systems of Medicine. Hbk Res. Vol. II, 1.15.4, Twelfth plenary meeting, 15 May 1987 - Committee A, fourth report: 1985 [cited 2009 March 10]. Available from: http://www.who.int/entity/medicines/areas/traditional/wha4033.pdf

[11] ASSOCHAM survey. December 7, 2007. 2007 [cited 2009 October 02]. Available from www.livemint.com

\title{
Parcerias entre os setores público e privado na prestação de serviços homeopáticos na cidade de Delhi, Índia
}

\begin{abstract}
RESUMO
A homeopatia é um dos sistemas médicos populares na Índia. Ao longo do tempo, o governo tem tentado difundir a homeopatia no sistema público de saúde, no entanto, a maioria dos prestadores do serviço pertence ao setor privado. Portanto, considera-se que uma política viável para melhorar a qualidade e a disponibilidade para todas as classes da população consistiria em parcerias entre os setores público e privado. Em Delhi, 90\% dos prestadores de serviços homeopáticos pertencem ao setor privado, incluindo fundações filantrópicas. A maioria deles atende a população de baixa renda em favelas urbanas. Em 2003, o governo de Delhi lançou um programa envolvendo o setor privado na prestação de serviços homeopáticos em áreas urbanas pouco cobertas por assistência médica. Esse projetou financiou entidades privadas para desenvolverem ambulatórios homeopáticos. Este artigo apresenta um panorama desse programa, focando em particular as lições que ensinam seis casos de estudo representados por organizações não governamentais (ONGs). Também discute as expectativas dos prestadores privados e conclui com recomendações específicas para uma participação mais ampla do setor privado.
\end{abstract}

Palavras-chave: Parceria público-privada, Serviços homeopáticos, Delhi, Organização não governamental, Custo-efetividade, Fatores críticos para o sucesso 


\section{Asociación de los sectores público y privado para atención homeopática en la ciudad de Delhi, Índia}

\section{RESUMEN}

La homeopatía es uno de los sistemas médicos populares en India. El gobierno intenta hace varios años difundir la homeopatía en el sistema público de salud, sin embargo, la mayoría de los prestadores de servicios pertenece al sector privado. Por ese motivo, se considera que la formación de sociedades público-privadas podría representar una política viable para mejorar la calidad y el acceso de todas las clases de la población. En Delhi, 90\% de los prestadores de servicios homeopáticos pertenecen al sector privado, incluyendo fundaciones filantrópicas. La mayoría atiende a la población de bajos recursos en villas miseria urbanas. En 2003, el gobierno de Delhi lanzó un programa involucrando al sector privado en la prestación de servicios homeopáticos en áreas asistencialmente poco cubiertas. Este proyecto financió entidades privadas que operasen consultorios homeopáticos. Este artículo presenta un panorama de este programa, con atención especial para las lecciones aprendidas a partir de seis estudios de caso representados por organizaciones no gubernamentales (ONGs). También discute las expectativas de los prestadores privados y concluye con recomendaciones específicas para la participación más amplia del sector privado.

Palabras-clave: Asociación público-privada, Servicios homeopáticos, Delhi, Organización no gubernamental, Costo-efectividad, Factores críticos para el éxito

\section{(c) BY-NC-ND Licensed to GIRI}

Support: authors declare that this study received no funding

Conflict of interest: authors declare there is no conflict of interest

Received: 11 August 2011; Revised: 29 November 2011; Published: 20 December 2011.

Correspondence author: A Venkat Raman, Faculty of Management Studies, University of Delhi, India. venkatfms@gmail.com

How to cite this article: Raman AV, Manchanda RK. Public-private partnerships in the provision of homeopathic services in the city of Delhi, India. Int J High Dilution Res [online]. 2011 [cited YYYY Month dd]; 10(37): 353-361. Available from: http://www.feg.unesp.br/ ojs/index.php/ijhdr/article/view/459/543 